\title{
TINJAUAN STRUKTUR GEDUNG RUMAH SAKIT UMUM DAERAH ULIN DI JALAN JENDERAL AHMAD YANI NO.43 BANJARMASIN
}

\author{
${ }^{1}$ Tanjung Rahayu, ${ }^{2}$ Nurul Najma \\ Program Studi Teknik Sipil Fakultas Teknik Universitas Suryakancana \\ nunajma28@gmail.com, tanjungrahayu@yahoo.com ${ }^{2}$
}

\begin{abstract}
Abstrak
Rumah Sakit Umum Daerah Ulin adalah rumah sakit kelas A Pendidikan yang berada di Kota Banjarmasin Kalimantan Selatan dan merupakan rumah sakit rujukan di Kalimantan Selatan. Berdasarkan kriteria kesalamatan dan layanan maka perhitungan pembebanan sesuai dengan SNI-1727-2013 serta perencanaan struktur gedung ini mengacu dengan SNI-2847-2013 beton bertulang, yang merupakan peraturan terbaru yang disesuaikan dengan perkembangan teknologi material terkini dengan mengacu pada AISC, selain itu dalam perhitungan rekayasa gempa juga mengacu pada SNI-1726-2012 dan SNI-1726-2002. Analisis struktur menggunakan software ETABS v16. Material beton digunakan untuk balok, kolom, serta plat. Terdapat tiga tipe balok, yaitu B3 dimensi $400 \times 700$ mm, B2 dimensi $300 \times 550$ mm, dan B1 dimensi $200 \times$ $400 \mathrm{~mm}$. Untuk kolom terdapat dua tipe yaitu dimensi $500 \times 800 \mathrm{~mm}$, dan dimensi $500 \times 500 \mathrm{~mm}$. Plat lantai dan plat atap setebal $120 \mathrm{~mm}$. Berdasarkan perhitungan, untuk kolom, balok, dan plat menggunakan tulangan yang bervariasi, tetapi antara bangunan $A, B$, dan $C$ perbedaan penulangannya tidak begitu jauh. Namun untuk plat lantai dan plat atap bangunan $C$ memerlukan tambahan balok di bagian tengah bentangnya untuk menghindari lendutan berlebih. Untuk dilatasi yaitu $130 \mathrm{~mm}$ dan sudah memenuhi syarat keamanan.
\end{abstract}

Kata kunci: Analisis sruktur, rekayasa gempa, beton, balok, kolom, plat, dan dilatasi

\section{PENDAhUluAN}

Rumah sakit merupakan bagian integral dari suatu organisasi sosial dan kesehatan dengan fungsi menyediakan pelayanan, penyembuhan penyakit dan pencegahan penyakit kepada masyarakat. Rumah sakit juga merupakan pusat pelatihan bagi tenaga kesehatan dan pusat penelitian medis. Rumah sakit harus dibangun, dilengkapi dan dipelihara dengan baik untuk menjamin kesehatan dan keselamatan pasiennya serta harus menyediakan fasilitas yang lapang dan terjamin bagi kesembuhan pasien.

Meningkatnya kebutuhan masyarakat akan pelayanan kesehatan, baik bagi masyarakat Banjarmasin maupun masyarakat sekitar Banjarmasin menyebabkan terjadi peningkatan permintaan terhadap fasilitas pelayanan kesehatan. Untuk memenuhi kebutuhan tersebut, maka Rumah Sakit Umum Daerah Ulin membangun gedung tambahan demi terpenuhinya kebutuhan dan meningkatkan pelayanan untuk masyarakat.

Dalam laporan tugas akhir ini dilakukan tinjauan struktur RSUD Ulin di jalan Jenderal Ahmad Yani No.43 Banjarmasin untuk mengetahui apakah struktur gedung tersebut aman, kuat, efisien, dan sesuai dengan SNI (Strandar Nasional Indonesia) sebagai acuan. Suatu konstruksi gedung harus mampu menahan beban dan gaya-gaya yang bekerja pada konstruksi itu sendiri, sehingga bangunan atau konstruksi gedung aman.

\section{A. Rumusan Masalah}

Berdasarkan latar belakang yang telah diuraikan di atas, dapat dirumuskan permasalahan yang akan diteliti, antara lain:

1. Bagaimana ketidakberaturan struktur horizontal dan vertikal yang terjadi pada RSUD Ulin di jalan Jenderal Ahmad Yani No.43 Banjarmasin?

2. Bagaimana keamanan jarak dilatasi pada struktur bangunan RSUD Ulin di jalan Jenderal Ahmad Yani No.43 Banjarmasin?

3. Bagaimana kekuatan dan keamanan struktur kolom, balok, dan pelat pada gedung RSUD Ulin di jalan Jenderal Ahmad Yani No.43 Banjarmasin, dalam memikul beban yang ditinjau?

\section{B. Tujuan Penelitian}

Adapun tujuan dari Penelitian yang dilaksanakan adalah:

1. Meninjau bangunan RSUD Ulin di jalan Jenderal Ahmad Yani No.43 Banjarmasin terhadap ketidakberaturan struktur. 
2. Meninjau keamanan jarak dilatasi RSUD Ulin di jalan Jenderal Ahmad Yani No.43 Banjarmasin.

3. Meninjau kekuatan dan keamanan dalam memikul beban yang terjadi pada struktur kolom, balok, dan pelat gedung RSUD Ulin di jalan Jenderal Ahmad Yani No.43 Banjarmasin, berdasarkan SNI menggunakan program Etabs dan Sp Column.

\section{METODOLOGI PENELITIAN}

\section{A. Informasi Umum Bangunan}

Gedung ini terdiri dari 7 lantai dengan tinggi masing-masing lantai adalah sebagai berikut:
1. Lantai
: 4,5 meter
2. Lantai $2-6: 4,2$ meter.
3. Lantai $7: 3$ meter

Langkah-langkah umum yang terdapat dalam analisis struktur dengan menggunakan aplikasi etabs adalah:

1. Membuat model struktur dalam bentuk 3 dimensi

2. Memasukkan data struktur yang akan digunakan seperti tipe material, section frame, load combination, dsb.

3. Analisa (run) gaya-gaya dalam struktur yang dimodelkan.

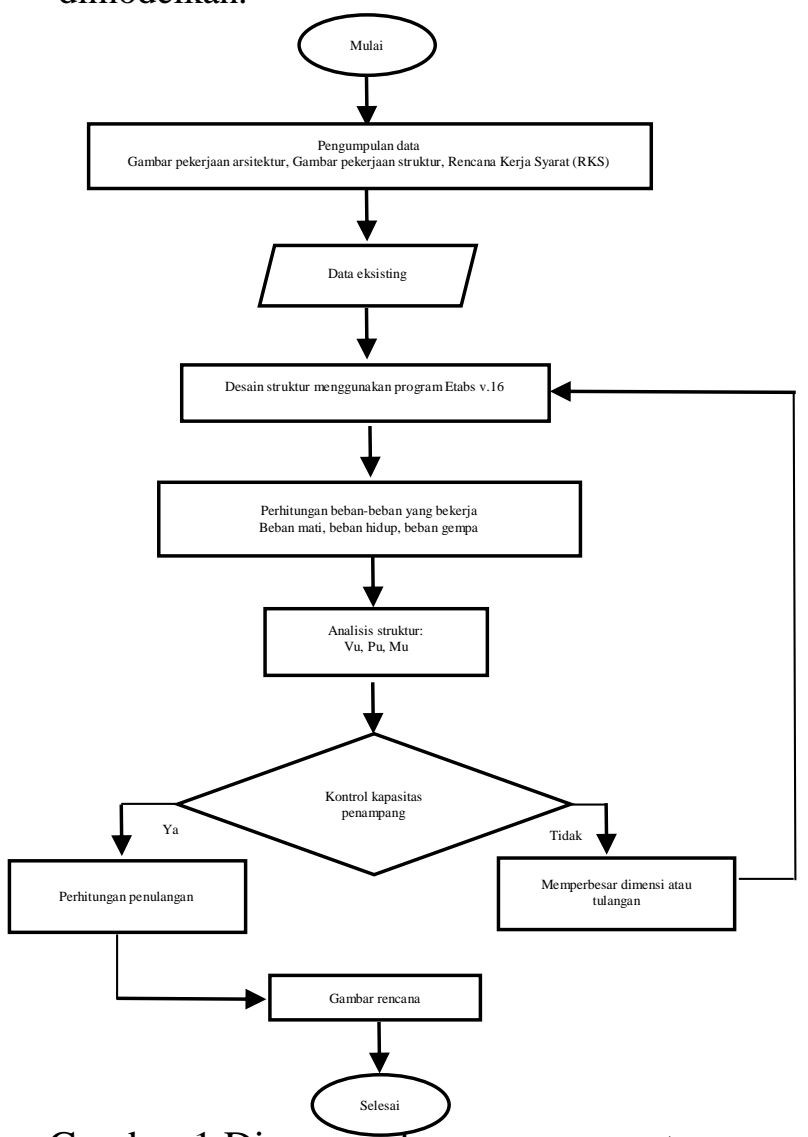

Gambar 1 Diagram alur penyusunan tugas

akhir

\section{B. Sistem Pembebanan}

Sistem pembebanan dalam perhitungan meliputi sistem pembebanan vertikal dan sistem pembebanan horizontal:

a. Beban vertikal

Beban mati, berupa berat sendiri struktur ditambah komponen-komponen lain yang berhubungan dan bersifat tetap.

Beban hidup, disebabkan penggunaan bangunan sesuai dengan fungsinya dan bersifat sementara.

b. Beban horizontal, berupa beban gempa. Sedangkan akibat beban angin tidak perlu diperhitungkan karena pengaruh beban gempa lebih besar sehingga yang diperhitungkan sebagai beban horizontal adalah beban gempa.

\section{Peraturan yang Digunakan}

Perhitungan struktur gedung memperhatikan ketentuan-ketentuan yang berlaku dan terdapat pada buku-buku sebagai pedoman, antara lain:

1. Peraturan Pembebanan Indonesia Untuk Gedung (PPIUG-1989).

2. Pedoman Perencanaan Pembebanan Untuk Rumah dan Gedung (SNI 03-1727-1989).

3. Beban Minimum untuk Perancangan Bangunan Gedung dan Struktur Lain (SNI 1727-2013).

4. Standar Perencanaan Ketahanan Gempa untuk Struktur Bangunan Gedung dan Non Gedung (SNI 1726:2012) dan SNI 1726:2002.

5. Persyaratan Beton Struktural untuk Bangunan Gedung (SNI 2847:2013).

\section{Data Struktur}

Adapun data-data yang Digunakan adalah sebagai berikut :

- Fungsi gedung $=$ Gedung rumah sakit

- Jenis struktur = Beton bertulang

- Sistem struktur $=$ SRPMM

- Jenis tanah = Tanah lunak

- Letak wilayah = Banjarmasin

- Jumlah lantai = 7 lantai

- Tinggi lantai $1=4,5 \mathrm{~m}$

- Tinggi lantai 2 - $6=4,2 \mathrm{~m}$

- Tinggi lantai $7=3 \mathrm{~m}$

- Tinggi total bangunan $=28,5 \mathrm{~m}$

- Mutu beton (fc') $=25 \mathrm{Mpa}$

- Mutu baja (fy) deform = $400 \mathrm{Mpa}$

- Mutu baja (fy) polos = $240 \mathrm{Mpa}$ 


\section{JURNAL MOMEN}

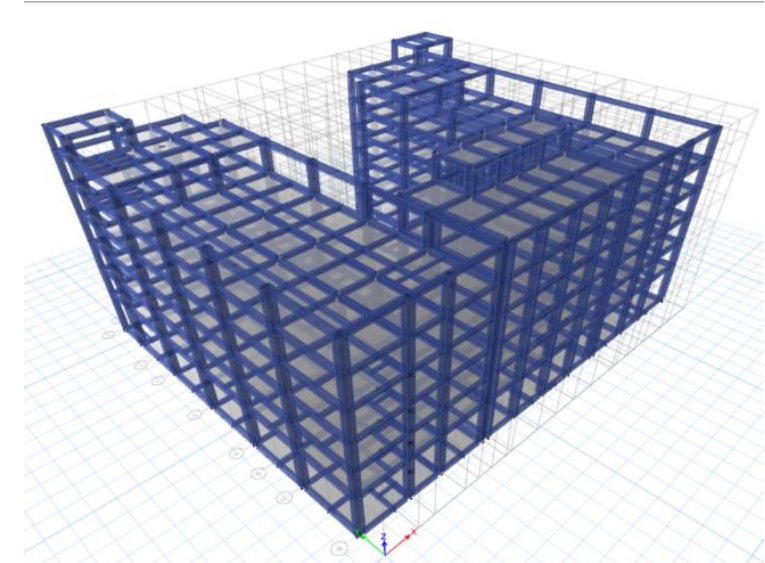

Gambar 2 Pemodelan Struktur tiga dimensi RSUD Ulin Banjarmasin

Untuk mengaplikasikan teori tentang pengaruh gempa pada bangunan asimetris, model bangunan akan dipisah menjadi tiga bagian sebagai berikut.

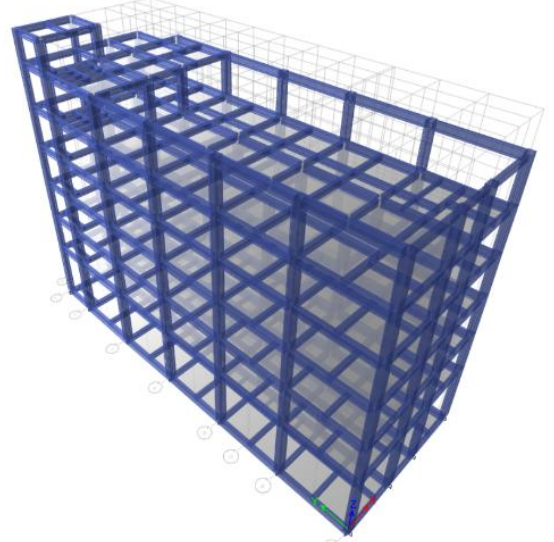

Gambar 3 Model struktur A

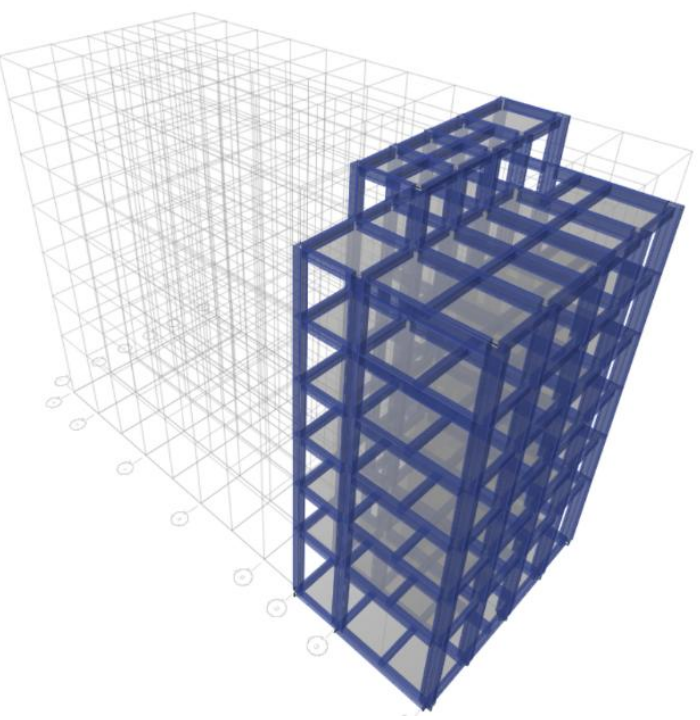

Gambar 4 Model struktur B

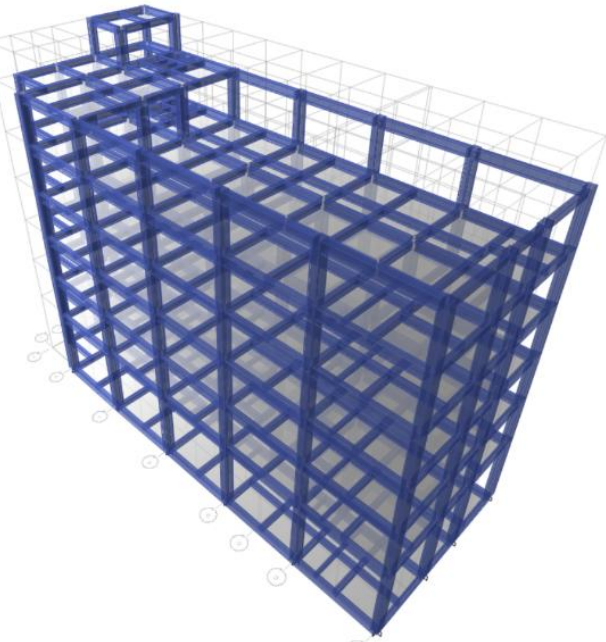

Gambar 5 Model struktur C

\section{ANALISIS PEMBEBANAN}

A. Perhitungan Gempa

Perhitungan beban gempa pada gedung perkuliahan ini, spektrum respons desain menggunakan program yang disediakan oleh dinas Pekerjaan Umum melalui situs puskim.pu.go.id.

- Kategori resiko = IV

- $\quad$ Kelas situs $=$ SE (tanah lunak)

- $(\mathrm{Ss})=0,061 \mathrm{~g}$

- $\quad(\mathrm{S} 1)=0,036 \mathrm{~g}$

- $\mathrm{Fa}=2,5$

- $\mathrm{Fv}=3,5$

- $\mathrm{SDS}=0,102 \mathrm{~g}$

- $\mathrm{SD} 1=0,084 \mathrm{~g}$

- Faktor keutamaan gempa (Ie) $=1,5$

- Koefisien modifikasi respons $(\mathrm{R})=5$

- Faktor kuat lebih sistem $(\Omega 0)=3$

- Faktor pembesaran defleksi $(\mathrm{Cd})=4,5$

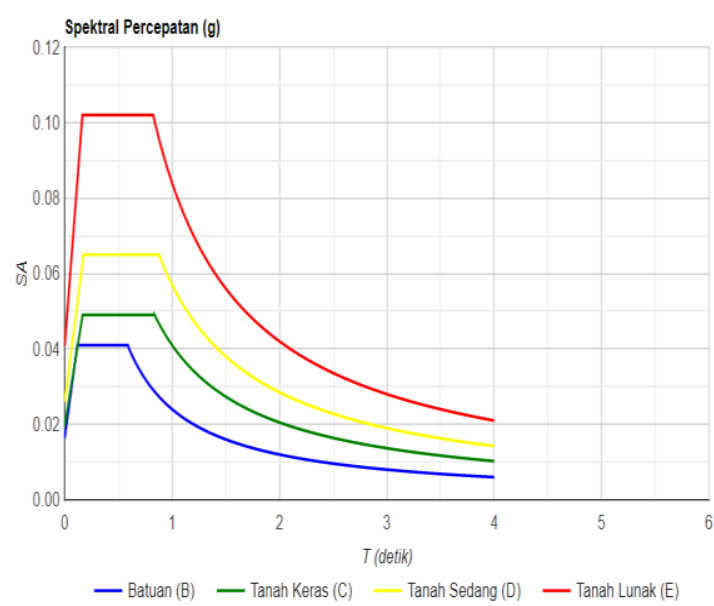

Gambar 6 Spektrum respon desain wilayah kota Banjarmasin 


\section{B. Periode Fundamental}

Dengan Rangka beton pemikul momen, penentuan fundamental pendekatan adalah sebagai berikut:

$$
\begin{aligned}
\mathrm{T}_{\text {min }} & =0,466\left(\mathrm{~h}_{\mathrm{n}}\right)^{0,90} \\
& =0,466 \times(30,5)^{0,90} \\
& =1,009 \\
\mathrm{~T}_{\text {maks }} & =\mathrm{C}_{\mathrm{u}} \times \mathrm{T}_{\text {min }} \\
& =1,7 \times 1,009 \\
& =1,564
\end{aligned}
$$

Nilai periode fundamental pendekatan struktur (T) juga harus dibandingkan dengan nilai $\mathrm{T}$ hasil dari program output etabs.

Untuk perhitungan nilai $\mathrm{T}$ bangunan $\mathrm{A}, \mathrm{B}$, dan $\mathrm{C}$ semuanya seragam dan memenuhi persamaan Tmin $<$ Tprogram < Tmaks. Sehingga untuk bangunan A nilai yang dipakai untuk $\mathrm{T}$ adalah $\mathrm{Tx}=1,303$ dan Ty $=1,307$. Bangunan $\mathrm{B} T \mathrm{Tx}=1,068$ dan $\mathrm{Ty}=$ 1,009. Bangunan $\mathrm{C}$ Tx $=1,304$ dan $\mathrm{Ty}=1,306$.

\section{Koefisien respon seismik}

Berdasarkan SNI 1726:2012 pasal 7.8.1.1 untuk menentukan nilai koefisien respon seismik $\left(\mathrm{C}_{\mathrm{s}}\right)$ adalah sebagai berikut:

Cs $=\mathrm{S}_{\mathrm{DS}} /\left(\mathrm{R} / \mathrm{I}_{\mathrm{e}}\right)$

$\mathrm{Cs}_{\max }=\mathrm{S}_{\mathrm{D} 1} /\left(\mathrm{T} \times\left(\mathrm{R} / \mathrm{I}_{\mathrm{e}}\right)\right)$

$\mathrm{Cs}_{\min }=0,044 \mathrm{~S}_{\mathrm{DS}} \mathrm{x}$ Ie

Dengan ketentuan: $\mathrm{Cs}_{\min }<\mathrm{Cs}<\mathrm{Cs}_{\max }$

Sehingga Cs dapat dihitung sebagai berikut:

Tabel 1 Perhitungan nilai Cs untuk bangunan

A, B, dan C RSUD Ulin

\begin{tabular}{lllll}
\hline & & $\mathrm{Cs}_{\min }$ & $\mathrm{Cs}$ & $\mathrm{Cs}_{\max }$ \\
\hline $\begin{array}{l}\text { Bangunan } \\
\text { arah x }\end{array}$ & $\mathrm{A}$ & 0,0067 & 0,0306 & 0,019 \\
\hline $\begin{array}{l}\text { Bangunan } \\
\text { arah y }\end{array}$ & $\mathrm{A}$ & 0,0067 & 0,0306 & 0,019 \\
\hline \multicolumn{5}{c}{ Maka digunakan $\mathrm{Cs}=0,0306$} \\
\hline $\begin{array}{l}\text { Bangunan } \\
\text { arah x }\end{array}$ & $\mathrm{B}$ & 0,0067 & 0,0306 & 0,024 \\
\hline $\begin{array}{l}\text { Bangunan } \\
\text { arah y }\end{array}$ & $\mathrm{B}$ & 0,0067 & 0,0306 & 0,025 \\
\hline \multicolumn{5}{c}{ Maka digunakan $\mathrm{Cs}=0,0306$} \\
\hline $\begin{array}{l}\text { Bangunan } \\
\text { arah x }\end{array}$ & $\mathrm{C}$ & 0,0067 & 0,0306 & 0,019 \\
\hline $\begin{array}{l}\text { Bangunan } \\
\text { arah y }\end{array}$ & $\mathrm{C}$ & 0,0067 & 0,0306 & 0,019 \\
\hline \multicolumn{5}{c}{ Maka digunakan $\mathrm{Cs}=0,0306$} \\
\hline
\end{tabular}

\section{Gaya geser desain seismik}

Gaya geser desain seismik dapat dihitung dengan persamaan:

$$
\mathrm{V}=\mathrm{C}_{\mathrm{s}} \mathrm{x} \mathrm{W}_{\text {total }}
$$

Sehingga, didapatkan nilai $\mathrm{V}$ pada bangunan $\mathrm{A}, \mathrm{B}$, dan $\mathrm{C}$ adalah sebagai berikut.
Tabel 2 Perhitungan gaya geser desain bangunan A, B, dan C

\begin{tabular}{ccc}
\hline Bangunan & Arah & Gaya geser \\
\hline Bangunan A & $\mathrm{x}$ & $942,167 \mathrm{kN}$ \\
\hline Bangunan A & $\mathrm{y}$ & $938,518 \mathrm{kN}$ \\
\hline Bangunan B & $\mathrm{x}$ & $343,049 \mathrm{kN}$ \\
\hline Bangunan B & $\mathrm{y}$ & $358,388 \mathrm{kN}$ \\
\hline Bangunan C & $\mathrm{x}$ & $918,860 \mathrm{kN}$ \\
\hline Bangunan C & $\mathrm{y}$ & $917,453 \mathrm{kN}$ \\
\hline
\end{tabular}

\section{E. Distribusi vertikal gaya gempa}

Berdasarkan SNI 1726 : 2012 pasal 7.8.3 untuk gaya gempa lateral $(\mathrm{Fx})$ yang timbul disemua tingkat harus ditentukan dari persamaan berikut.

$$
\text { Fx }=\mathrm{C}_{\mathrm{vx}} \mathrm{x} \mathrm{V}
$$

Dengan $\mathrm{Cv}$ yang diambil dari persamaan berikut:

$\mathrm{C}_{\mathrm{vx}}=\frac{W i_{x} h_{x}^{k}}{\sum_{i=1}^{n} W_{i} h_{x}^{k}}$

Tabel 3 Distribusi vertikal gempa pada bangunan A $\operatorname{arah} x$

\begin{tabular}{|c|c|c|c|c|c|c|c|}
\hline $\begin{array}{c}\text { Lantai } \\
\text { ke }\end{array}$ & (hi) & (Wi) & $\mathrm{k}$ & wix hil $^{\mathrm{k}}$ & $\mathrm{Cvx}$ & $\mathrm{Fx}(\mathrm{kg})$ & $\mathrm{Fx}(\mathrm{kN})$ \\
\hline 7 & 30,5 & 11351,25 & 1,4 & 1358511,952 & 0,006700683843 & 643,5439484 & 6,313166133 \\
\hline 6 & 27,5 & 133156,48 & 1,4 & 13785676,32 & 0,06799605881 & 6530,445725 & 64,06367256 \\
\hline 5 & 23,3 & 549440,395 & 1,4 & 45104396,38 & 0,2224715797 & 21366,51156 & 209,6054784 \\
\hline 4 & 19,1 & 896424,99 & 1,4 & 55713529,1 & 0,2747997496 & 26392,18921 & 258,9073762 \\
\hline 3 & 14,9 & 937583,705 & 1,4 & 41159569,77 & 0,2030142346 & 19497,79831 & 191,2734014 \\
\hline 2 & 10,7 & 937583,915 & 1,4 & 25890917,26 & 0,1277035882 & 12264,84838 & 120,3181626 \\
\hline 1 & 6,5 & 1435626,385 & 1,4 & 19729684,06 & 0,09731410533 & 9346,195857 & 91,68618136 \\
\hline Total & & 4901167,12 & & 202742284,9 & 1 & 96041,53299 & 942,1674386 \\
\hline
\end{tabular}

Tabel 4 Distribusi vertikal gempa pada bangunan A arah y

\begin{tabular}{|c|c|c|c|c|c|c|c|}
\hline $\begin{array}{c}\text { Lantai } \\
\mathrm{ke}\end{array}$ & $(\mathrm{hi})$ & $(\mathrm{Wi})$ & $\mathrm{k}$ & wi $\mathrm{xh} \mathrm{i}^{\mathrm{k}}$ & $\mathrm{Cvx}$ & $\mathrm{Fx}(\mathrm{kg})$ & $\mathrm{Fx}(\mathrm{kN})$ \\
\hline 7 & 30,5 & 11351,25 & 1,4 & 1358511,952 & 0,006700683843 & 641,0515241 & 6,288715451 \\
\hline 6 & 27,5 & 133156,48 & 1,4 & 13785676,32 & 0,06799605881 & 6505,153526 & 63,81555609 \\
\hline 5 & 23,3 & 549440,395 & 1,4 & 45104396,38 & 0,2224715797 & 21283,75977 & 208,7936834 \\
\hline 4 & 19,1 & 896424,99 & 1,4 & 55713529,1 & 0,2747997496 & 26289,97314 & 257,9046365 \\
\hline 3 & 14,9 & 937583,705 & 1,4 & 41159569,77 & 0,2030142346 & 19422,28398 & 190,5326059 \\
\hline 2 & 10,7 & 937583,915 & 1,4 & 25890917,26 & 0,1277035882 & 12217,34703 & 119,8521744 \\
\hline 1 & 6,5 & 1435626,385 & 1,4 & 19729684,06 & 0,09731410533 & 9309,998352 & 91,33108383 \\
\hline Total & & 4901167,12 & & 202742284,9 & 1 & 95669,56733 & 938,5184555 \\
\hline
\end{tabular}

Tabel 5 Distribusi vertikal gempa pada bangunan $\mathrm{B}$ arah $\mathrm{x}$

\begin{tabular}{|c|c|c|c|c|c|c|c|}
\hline $\begin{array}{c}\text { Lantai } \\
\text { ke }\end{array}$ & (hi) & $(\mathrm{Wi})$ & $\mathrm{k}$ & wi $\mathrm{hi}^{\mathrm{k}}$ & $\mathrm{Cvx}$ & $\mathrm{Fx}(\mathrm{kg})$ & $\mathrm{Fx}(\mathrm{kN})$ \\
\hline 7 & 30,5 & 36978,8 & 1,28 & 2936679,882 & 0,05724026093 & 2001,657476 & 19,63625984 \\
\hline 6 & 27,5 & 136902,39 & 1,28 & 9522629,295 & 0,1856102154 & 6490,677529 & 63,67354656 \\
\hline 5 & 23,3 & 217314,375 & 1,28 & 12226552,98 & 0,2383137117 & 8333,687076 & 81,75347021 \\
\hline 4 & 19,1 & 234781,57 & 1,28 & 10242045,78 & 0,1996327132 & 6981,035836 & 68,48396155 \\
\hline 3 & 14,9 & 234781,57 & 1,28 & 7453194,006 & 0,1452738421 & 5080,138831 & 49,83616193 \\
\hline 2 & 10,7 & 234781,57 & 1,28 & 4878375,634 & 0,09508680054 & 3325,12819 & 32,61950754 \\
\hline 1 & 6,5 & 368456,355 & 1,28 & 4044968,538 & 0,07884245605 & 2757,073239 & 27,04688847 \\
\hline Total & & 1463996,63 & & 51304446,11 & 1 & 34969,39818 & 343,0497961 \\
\hline
\end{tabular}


Tabel 6 Distribusi vertikal gempa pada bangunan B arah y

\begin{tabular}{|c|c|c|c|c|c|c|c|}
\hline $\begin{array}{c}\text { Lantai } \\
\text { ke }\end{array}$ & (hi) & (Wi) & $\mathrm{k}$ & wi hil $^{\mathrm{k}}$ & $\mathrm{Cvx}$ & $\mathrm{Fx}(\mathrm{kg})$ & $\mathrm{Fx}(\mathrm{kN})$ \\
\hline 7 & 30,5 & 36978,8 & 1,25 & 2650498,806 & 0,05637950128 & 2059,709991 & 20,20575501 \\
\hline 6 & 27,5 & 136902,39 & 1,25 & 8621382,175 & 0,1833878311 & 6699,700057 & 65,72405756 \\
\hline 5 & 23,3 & 217314,375 & 1,25 & 11124573,16 & 0,2366339065 & 8644,936729 & 84,80682931 \\
\hline 4 & 19,1 & 234781,57 & 1,25 & 9374664,011 & 0,1994110997 & 7285,077465 & 71,46660993 \\
\hline 3 & 14,9 & 234781,57 & 1,25 & 6873007,819 & 0,1461976713 & 5341,033483 & 52,39553847 \\
\hline 2 & 10,7 & 234781,57 & 1,25 & 4543533,396 & 0,0966467694 & 3530,792433 & 34,63707377 \\
\hline 1 & 6,5 & 368456,355 & 1,25 & 3824086,851 & 0,08134322077 & 2971,708524 & 29,15246062 \\
\hline Total & & 1463996,63 & & 47011746,22 & 1 & 36532,95868 & 358,3883247 \\
\hline
\end{tabular}

Tabel 7 Distribusi vertikal gempa pada bangunan $\mathrm{C} \operatorname{arah} \mathrm{x}$

\begin{tabular}{|c|c|c|c|c|c|c|c|}
\hline $\begin{array}{c}\text { Lantai } \\
\text { ke }\end{array}$ & $(\mathrm{hi})$ & $(\mathrm{Wi})$ & $\mathrm{k}$ & wi $\mathrm{hi}^{\mathrm{k}}$ & $\mathrm{Cvx}$ & $\mathrm{Fx}(\mathrm{kg})$ & $\mathrm{Fx}(\mathrm{kN})$ \\
\hline 7 & 30,5 & 11351,25 & 1,4 & 1358511,952 & 0,006753565448 & 632,5771434 & 6,205581777 \\
\hline 6 & 27,5 & 132619,54 & 1,4 & 13730086,98 & 0,06825633067 & 6393,274042 & 62,71801836 \\
\hline 5 & 23,3 & 550728,925 & 1,4 & 45210173,76 & 0,2247531697 & 21051,65326 & 206,5167185 \\
\hline 4 & 19,1 & 891151,325 & 1,4 & 55385766,61 & 0,2753390569 & 25789,8136 & 252,9980714 \\
\hline 3 & 14,9 & 923382,02 & 1,4 & 40536121,18 & 0,2015170694 & 18875,22866 & 185,1659931 \\
\hline 2 & 10,7 & 923382,29 & 1,4 & 25498746,39 & 0,1267618237 & 11873,22947 & 116,4763811 \\
\hline 1 & 6,5 & 1414210,7 & 1,4 & 19435370,23 & 0,09661898421 & 9049,880615 & 88,77932883 \\
\hline Total & & 4846826,05 & & 201154777,1 & 1 & 93665,65679 & 918,8600932 \\
\hline
\end{tabular}

Tabel 8 Distribusi vertikal gempa pada bangunan $\mathrm{C}$ arah y

\begin{tabular}{|c|c|c|c|c|c|c|c|}
\hline $\begin{array}{c}\text { Lantai } \\
\text { ke }\end{array}$ & (hi) & (Wi) & $\mathrm{k}$ & wi $\mathrm{hi}^{\mathrm{k}}$ & $\mathrm{Cvx}$ & $\mathrm{Fx}(\mathrm{kg})$ & $\mathrm{Fx}(\mathrm{kN})$ \\
\hline 7 & 30,5 & 11351,25 & 1,4 & 1358511,952 & 0,006753565448 & 631,6084188 & 6,196078589 \\
\hline 6 & 27,5 & 132619,54 & 1,4 & 13730086,98 & 0,06825633067 & 6383,483424 & 62,62197239 \\
\hline 5 & 23,3 & 550728,925 & 1,4 & 45210173,76 & 0,2247531697 & 21019,41489 & 206,2004601 \\
\hline 4 & 19,1 & 891151,325 & 1,4 & 55385766,61 & 0,2753390569 & 25750,31925 & 252,6106318 \\
\hline 3 & 14,9 & 923382,02 & 1,4 & 40536121,18 & 0,2015170694 & 18846,32326 & 184,8824311 \\
\hline 2 & 10,7 & 923382,29 & 1,4 & 25498746,39 & 0,1267618237 & 11855,04689 & 116,2980099 \\
\hline 1 & 6,5 & 1414210,7 & 1,4 & 19435370,23 & 0,09661898421 & 9036,021686 & 88,64337274 \\
\hline Total & & 4846826,05 & & 201154777,1 & 1 & 93522,21781 & 917,4529567 \\
\hline
\end{tabular}

\section{F. Distribusi horizontal gaya gempa}

Berdasarkan SNI 1726 : 2012 pasal 7.8.3 untuk gaya geser tingkat desain gempa di semua tingkat (Vx) harus ditentukan bedasarkan pada persamaan berikut.

$$
\mathrm{Vx}=\sum_{i=1}^{n} F_{x i}
$$

Tabel 9 Gaya geser tingkat di semua tingkat Bangunan A arah x dan y

\begin{tabular}{|c|c|c|c|c|c|}
\hline \multirow{2}{*}{$\begin{array}{c}\text { Lantai } \\
\mathrm{ke}\end{array}$} & \multirow{2}{*}{ Tinggi } & \multicolumn{2}{|c|}{ Arah x } & \multicolumn{2}{c|}{ Arah y } \\
\cline { 3 - 6 } & & $\mathrm{Fx}(\mathrm{kN})$ & $\mathrm{Vx}(\mathrm{kN})$ & Fx $(\mathrm{kN})$ & $\mathrm{Vx}(\mathrm{kN})$ \\
\hline 7 & 30,5 & 6,313166133 & 6,313166133 & 6,288715451 & 6,288715451 \\
\hline 6 & 27,5 & 64,06367256 & 70,3768387 & 63,81555609 & 70,10427154 \\
\hline 5 & 23,3 & 209,6054784 & 279,9823171 & 208,7936834 & 278,8979549 \\
\hline 4 & 19,1 & 258,9073762 & 538,8896933 & 257,9046365 & 536,8025914 \\
\hline 3 & 14,9 & 191,2734014 & 730,1630946 & 190,5326059 & 727,3351973 \\
\hline 2 & 10,7 & 120,3181626 & 850,4812573 & 119,8521744 & 847,1873717 \\
\hline 1 & 6,5 & 91,68618136 & 942,1674386 & 91,33108383 & 938,5184555 \\
\hline
\end{tabular}

Tabel 10 Gaya geser tingkat di semua tingkat Bangunan A arah $\mathrm{x}$ dan $\mathrm{y}$

\begin{tabular}{|c|c|c|c|c|c|}
\hline \multirow{2}{*}{$\begin{array}{c}\text { Lantai } \\
\text { ke }\end{array}$} & \multirow{2}{*}{ Tinggi } & \multicolumn{2}{|c|}{ Arah $\mathrm{x}$} & \multicolumn{2}{c|}{ Arah y } \\
\cline { 3 - 6 } & & Fx (kN) & Vx (kN) & Fx (kN) & Vx (kN) \\
\hline 7 & 30,5 & 19,63625984 & 19,63625984 & 20,20575501 & 20,20575501 \\
\hline 6 & 27,5 & 63,67354656 & 83,3098064 & 65,72405756 & 85,92981257 \\
\hline 5 & 23,3 & 81,75347021 & 165,0632766 & 84,80682931 & 170,7366419 \\
\hline 4 & 19,1 & 68,48396155 & 233,5472382 & 71,46660993 & 242,2032518 \\
\hline 3 & 14,9 & 49,83616193 & 283,3834001 & 52,39553847 & 294,5987903 \\
\hline 2 & 10,7 & 32,61950754 & 316,0029076 & 34,63707377 & 329,2358641 \\
\hline 1 & 6,5 & 27,04688847 & 343,0497961 & 29,15246062 & 358,3883247 \\
\hline
\end{tabular}

Tabel 11 Gaya geser tingkat di semua tingkat Bangunan A arah x dan y

\begin{tabular}{|c|c|c|c|c|c|}
\hline \multirow{2}{*}{$\begin{array}{c}\text { Lantai } \\
\text { ke }\end{array}$} & \multirow{2}{*}{ Tinggi } & \multicolumn{2}{|c|}{ Arah x } & \multicolumn{2}{c|}{ Arah y } \\
\cline { 3 - 6 } & & Fx (kN) & Vx (kN) & Fx (kN) & Vx (kN) \\
\hline 7 & 30,5 & 6,205581777 & 6,205581777 & 6,196078589 & 6,196078589 \\
\hline 6 & 27,5 & 62,71801836 & 68,92360013 & 62,62197239 & 68,81805097 \\
\hline 5 & 23,3 & 206,5167185 & 275,4403186 & 206,2004601 & 275,0185111 \\
\hline 4 & 19,1 & 252,9980714 & 528,43839 & 252,6106318 & 527,6291429 \\
\hline 3 & 14,9 & 185,1659931 & 713,6043832 & 184,8824311 & 712,511574 \\
\hline 2 & 10,7 & 116,4763811 & 830,0807643 & 116,2980099 & 828,809584 \\
\hline 1 & 6,5 & 88,77932883 & 918,8600932 & 88,64337274 & 917,4529567 \\
\hline
\end{tabular}

\section{G. Simpangan antar lantai}

Untuk memperoleh simpangan antar lantai, diperlukan perhitungan sebagai berikut:

- $\delta$ Total $=$ simpangan total hasil output program etabs

- $\delta$ xe = simpangan antar lantai, didapatkan dari simpangan total lantai yang ditinjau simpangan total lantai di bawahnya.

- $\delta \mathrm{x}=$ simpangan arah $\mathrm{x}$, didapatkan dari hasil perhitungan $\Delta$ xe dikali $\mathrm{Cd}$

- $\quad$ Izin = simpangan yang diijinkan, didapatkan dari tabel 4.30 dikali tinggi antar lantai.

- $\quad \mathrm{Cd}=$ Faktor pembesaran defleksi $(0,010 \times \mathrm{h})$

Tabel 12 Simpangan antar lantai arah $\mathrm{x}$ bangunan $\mathrm{A}$

\begin{tabular}{|c|c|c|c|c|c|c|c|c|}
\hline \multirow[t]{2}{*}{ Lantai } & \multirow[t]{2}{*}{ Arah } & $\delta$ Total & $\delta x e$ & \multirow[t]{2}{*}{ Cd } & \multirow{2}{*}{$\begin{array}{c}\delta \mathbf{x} \\
\mathbf{m m}\end{array}$} & \multirow{2}{*}{$\begin{array}{c}\begin{array}{c}\text { Tinggi } \\
\text { Tingkat }\end{array} \\
\mathrm{mm}\end{array}$} & \multirow{2}{*}{$\begin{array}{c}\text { ózzin } \\
\text { mm }\end{array}$} & \multirow[t]{2}{*}{ Cek } \\
\hline & & $\mathrm{mm}$ & $\mathrm{mm}$ & & & & & \\
\hline 7 & $\mathrm{X}$ & 14,154 & 0,557 & 4,5 & 2,5065 & 3000 & 30 & OK \\
\hline 6 & $\mathrm{X}$ & 13,597 & 1.585 & 4,5 & 7,1325 & 4200 & 42 & OK \\
\hline 5 & $\mathrm{X}$ & 12,012 & 1,444 & 4,5 & 6,498 & 4200 & 42 & OK \\
\hline 4 & $\mathrm{X}$ & 10,568 & 1,987 & 4,5 & 8,9415 & 4200 & 42 & OK \\
\hline 3 & $\mathrm{X}$ & 8,581 & 2,442 & 4,5 & 10,989 & 4200 & 42 & OK \\
\hline 2 & $\mathrm{X}$ & 6,139 & 2,711 & 4,5 & 12,1995 & 4200 & 42 & OK \\
\hline 1 & $\mathrm{X}$ & 3,428 & 3,428 & 4,5 & 15,426 & 6500 & 65 & OK \\
\hline
\end{tabular}


Tabel 13 Simpangan antar lantai arah y bangunan $\mathrm{A}$

\begin{tabular}{|c|c|c|c|c|c|c|c|c|}
\hline \multirow[t]{2}{*}{ Lantai } & \multirow[t]{2}{*}{ Arah } & \multirow{2}{*}{$\begin{array}{c}\text { ¿Total } \\
\mathrm{mm}\end{array}$} & \multirow{2}{*}{$\begin{array}{c}\delta \mathrm{xe} \\
\mathrm{mm}\end{array}$} & \multirow[t]{2}{*}{ Cd } & \multirow{2}{*}{$\begin{array}{c}\delta \mathrm{x} \\
\mathrm{mm}\end{array}$} & \multirow{2}{*}{$\begin{array}{c}\begin{array}{c}\text { Tinggi } \\
\text { Tingkat }\end{array} \\
\mathrm{mm}\end{array}$} & \multirow{2}{*}{$\begin{array}{c}\text { oIzin } \\
\text { mm }\end{array}$} & \multirow[t]{2}{*}{ Cek } \\
\hline & & & & & & & & \\
\hline 7 & $\mathrm{Y}$ & 12,164 & 0,31 & 4,5 & 1,395 & 3000 & 30 & OK \\
\hline 6 & $\mathrm{Y}$ & 11,854 & 0,531 & 4,5 & 2,3895 & 4200 & 42 & $\mathrm{OK}$ \\
\hline 5 & $\mathrm{Y}$ & 11,323 & 0,991 & 4,5 & 4,4595 & 4200 & 42 & OK \\
\hline 4 & $\mathrm{Y}$ & 10,332 & 1,521 & 4,5 & 6,8445 & 4200 & 42 & $\mathrm{OK}$ \\
\hline 3 & $\mathrm{Y}$ & 8,811 & 1,928 & 4,5 & 8,676 & 4200 & 42 & $\mathrm{OK}$ \\
\hline 2 & $\mathrm{Y}$ & 6,883 & 2,293 & 4,5 & 10,3185 & 4200 & 42 & $\mathrm{OK}$ \\
\hline 1 & $\mathrm{Y}$ & 4,59 & 4,59 & 4,5 & 20,655 & 6500 & 65 & $\mathrm{OK}$ \\
\hline
\end{tabular}

Tabel 14 Simpangan antar lantai arah $\mathrm{x}$ bangunan B

\begin{tabular}{|c|c|c|c|c|c|c|c|c|}
\hline \multirow[t]{2}{*}{ Lantai } & \multirow[t]{2}{*}{ Arah } & \multirow{2}{*}{$\begin{array}{c}\delta \text { Total } \\
\mathrm{mm}\end{array}$} & \multirow{2}{*}{$\begin{array}{l}\delta \mathrm{xe} \\
\mathrm{mm}\end{array}$} & \multirow[t]{2}{*}{ Cd } & \multirow{2}{*}{$\begin{array}{c}\delta \mathbf{x} \\
\mathrm{mm}\end{array}$} & \multirow{2}{*}{$\begin{array}{c}\begin{array}{c}\text { Tinggi } \\
\text { Tingkat }\end{array} \\
\mathrm{mm}\end{array}$} & \multirow{2}{*}{ 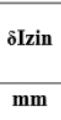 } & \multirow[t]{2}{*}{ Cek } \\
\hline & & & & & & & & \\
\hline 7 & $\mathrm{x}$ & 9,247 & 0,35 & 4,5 & 1,575 & 3000 & 30 & OK \\
\hline 6 & $\mathrm{x}$ & 8,897 & 0,632 & 4,5 & 2,844 & 4200 & 42 & $\mathrm{OK}$ \\
\hline 5 & $\mathrm{X}$ & 8,265 & 0,953 & 4,5 & 4,2885 & 4200 & 42 & $\mathrm{OK}$ \\
\hline 4 & $\mathrm{x}$ & 7,312 & 1,226 & 4,5 & 5,517 & 4200 & 42 & $\mathrm{OK}$ \\
\hline 3 & $\mathrm{x}$ & 6,086 & 1,426 & 4,5 & 6,417 & 4200 & 42 & OK \\
\hline 2 & $\mathrm{X}$ & 4,66 & 1,635 & 4,5 & 7,3575 & 4200 & 42 & OK \\
\hline 1 & $\mathrm{x}$ & 3,025 & 3,025 & 4,5 & 13,6125 & 6500 & 65 & OK \\
\hline
\end{tabular}

Tabel 15 Simpangan antar lantai arah y bangunan B

\begin{tabular}{|c|c|c|c|c|c|c|c|c|}
\hline \multirow[t]{2}{*}{ Lantai } & \multirow[t]{2}{*}{ Arah } & \multirow{2}{*}{$\begin{array}{c}\delta \text { Total } \\
\mathrm{mm}\end{array}$} & \multirow{2}{*}{$\begin{array}{c}\text { oxe } \\
\mathrm{mm}\end{array}$} & \multirow[t]{2}{*}{ Cd } & \multirow{2}{*}{$\begin{array}{c}\delta \mathbf{x} \\
\mathrm{mm}\end{array}$} & \multirow{2}{*}{$\begin{array}{c}\begin{array}{c}\text { Tinggi } \\
\text { Tingkat }\end{array} \\
\mathrm{mm}\end{array}$} & \multirow{2}{*}{$\begin{array}{c}\text { oIzin } \\
\text { mm }\end{array}$} & \multirow[t]{2}{*}{ Cek } \\
\hline & & & & & & & & \\
\hline 7 & $\mathrm{Y}$ & 9,7 & 0,443 & 4,5 & 1,9935 & 3000 & 30 & $\mathrm{OK}$ \\
\hline 6 & $\mathrm{Y}$ & 9,257 & 0,832 & 4,5 & 3,744 & 4200 & 42 & OK \\
\hline 5 & $\mathrm{Y}$ & 8,425 & 1,159 & 4,5 & 5,2155 & 4200 & 42 & $\mathrm{OK}$ \\
\hline 4 & Y & 7,266 & 1,448 & 4,5 & 6,516 & 4200 & 42 & OK \\
\hline 3 & $\mathrm{Y}$ & 5,818 & 1,659 & 4,5 & 7,4655 & 4200 & 42 & $\mathrm{OK}$ \\
\hline 2 & $\mathrm{Y}$ & 4,159 & 1,791 & 4,5 & 8,0595 & 4200 & 42 & OK \\
\hline 1 & $\mathrm{Y}$ & 2,368 & 2,368 & 4,5 & 10,656 & 6500 & 65 & OK \\
\hline
\end{tabular}

Tabel 16 Simpangan antar lantai arah $\mathrm{x}$ bangunan $\mathrm{C}$

\begin{tabular}{|c|c|c|c|c|c|c|c|c|}
\hline \multirow[t]{2}{*}{ Lantai } & \multirow[t]{2}{*}{ Arah } & \multirow{2}{*}{$\begin{array}{c}\delta \text { Total } \\
\mathrm{mm}\end{array}$} & \multirow{2}{*}{$\begin{array}{c}\text { oxe } \\
\mathrm{mm}\end{array}$} & \multirow[t]{2}{*}{ Cd } & \multirow{2}{*}{$\begin{array}{c}\delta \mathrm{x} \\
\mathrm{mm}\end{array}$} & \multirow{2}{*}{$\begin{array}{c}\begin{array}{c}\text { Tinggi } \\
\text { Tingkat }\end{array} \\
\mathbf{m m}\end{array}$} & \multirow{2}{*}{$\begin{array}{r}\text { oIzin } \\
\mathrm{mm}\end{array}$} & \multirow[t]{2}{*}{ Cek } \\
\hline & & & & & & & & \\
\hline 7 & $\mathrm{Y}$ & 14,024 & 0,568 & 4,5 & 2,556 & 3000 & 30 & OK \\
\hline 6 & $\mathrm{Y}$ & 13,456 & 1,575 & 4,5 & 7,0875 & 4200 & 42 & $\mathrm{OK}$ \\
\hline 5 & $\mathrm{Y}$ & 11,881 & 1,432 & 4,5 & 6,444 & 4200 & 42 & $\mathrm{OK}$ \\
\hline 4 & $\mathrm{Y}$ & 10,449 & 1,97 & 4,5 & 8,865 & 4200 & 42 & OK \\
\hline 3 & $\mathrm{Y}$ & 8,479 & 2,417 & 4,5 & 10,8765 & 4200 & 42 & $\mathrm{OK}$ \\
\hline 2 & $\mathrm{Y}$ & 6,062 & 2,68 & 4,5 & 12,06 & 4200 & 42 & $\mathrm{OK}$ \\
\hline 1 & $\mathrm{Y}$ & 3,382 & 3,382 & 4,5 & 15,219 & 6500 & 65 & OK \\
\hline
\end{tabular}

Tabel 17 Simpangan antar lantai arah y bangunan $\mathrm{C}$

\begin{tabular}{|c|c|c|c|c|c|c|c|c|}
\hline \multirow[t]{2}{*}{ Lantai } & \multirow[t]{2}{*}{ Arah } & $\delta$ Total & $\delta x e$ & \multirow[t]{2}{*}{ Cd } & \multirow{2}{*}{$\begin{array}{c}\delta \mathbf{x} \\
\mathbf{m m}\end{array}$} & \multirow{2}{*}{$\begin{array}{c}\begin{array}{c}\text { Tinggi } \\
\text { Tingkat }\end{array} \\
\mathbf{m m}\end{array}$} & \multirow{2}{*}{$\begin{array}{c}\text { סIzin } \\
\text { mm }\end{array}$} & \multirow[t]{2}{*}{ Cek } \\
\hline & & mm & $\mathrm{mm}$ & & & & & \\
\hline 7 & $\mathrm{Y}$ & 11,212 & 0,293 & 4,5 & 1,3185 & 3000 & 30 & OK \\
\hline 6 & Y & 10,919 & 0,49 & 4,5 & 2,205 & 4200 & 42 & OK \\
\hline 5 & $\mathrm{Y}$ & 10,429 & 0,919 & 4,5 & 4,1355 & 4200 & 42 & OK \\
\hline 4 & $\mathrm{Y}$ & 9,51 & 1,404 & 4,5 & 6,318 & 4200 & 42 & OK \\
\hline 3 & $\mathrm{Y}$ & 8,106 & 1,777 & 4,5 & 7,9965 & 4200 & 42 & OK \\
\hline 2 & Y & 6,329 & 2,11 & 4,5 & 9,495 & 4200 & 42 & OK \\
\hline 1 & $\mathrm{Y}$ & 4,219 & 4,219 & 4,5 & 18,9855 & 6500 & 65 & OK \\
\hline
\end{tabular}

\section{H. Pengaruh P-Delta}

Struktur untuk bangunan tahan gempa harus diperhitungkan terhadap pengaruh P-delta yang dapat dihitung dengan rumus sebagai berikut.

$$
\theta=\frac{P_{x} \Delta I_{\varepsilon}}{V_{x} h_{s x} C_{d}}
$$

Nilai koefisien stabilitas $(\Theta)$ tidak boleh melebihi (Өmax) yang ditentukan perumusan berikut:

$$
\theta_{\max }=\frac{0,5}{\beta C_{d}} \leq 0,25
$$

Sehingga diperoleh:

Tabel 18. Nilai teta max

\begin{tabular}{|l|l|}
\hline Beta & 1 \\
\hline Cd & 4.5 \\
\hline Teta max & 0,11111 \\
\hline
\end{tabular}

Setelah dilakukan pengecekan, bangunan A,B, dan $\mathrm{C}$ arah $\mathrm{x}$ dan $\mathrm{y}$ aman terhadap pengaruh P-Delta.

\section{Ketidakberaturan Struktur}

Setelah dilakukan semua pengecekan ketidakberaturan struktur vertikal, maka dapat disimpulkan jika bangunan $\mathrm{A}, \mathrm{B}$, dan $\mathrm{C}$ tidak mengalami ketidakberaturan vertikal. 
Tabel 19. Struktur RSUD Ulin terhadap ketidakberaturan vertikal dan horizontal

\begin{tabular}{|c|c|c|c|}
\hline $\begin{array}{l}\text { Ketidakberaturan } \\
\text { horizontal }\end{array}$ & Cek & $\begin{array}{l}\text { Ketidakberatur } \\
\text { an vertikal }\end{array}$ & $\begin{array}{l}\mathrm{C} \\
\mathrm{e} \\
\mathrm{k}\end{array}$ \\
\hline $\begin{array}{l}\text { 1. Ketidakberatura } \\
\mathrm{n} \text { torsi }\end{array}$ & $x$ & $\begin{array}{l}\text { 1. Ketidakberatu } \\
\text { ran kekakuan } \\
\text { tingkat lunak }\end{array}$ & $x$ \\
\hline $\begin{array}{c}\text { 2. Ketidakberaturan } \\
\text { sudut dalam }\end{array}$ & $x$ & $\begin{array}{l}\text { 2. Ketidakberatu } \\
\text { ran berat massa }\end{array}$ & $x$ \\
\hline $\begin{array}{l}\text { 3. Ketidakberaturan } \\
\text { diskontinuitas } \\
\text { diafragma }\end{array}$ & $x$ & $\begin{array}{l}\text { 3. Ketidakberatu } \\
\text { ran geometri } \\
\text { vertikal }\end{array}$ & $x$ \\
\hline $\begin{array}{l}\text { 4.Ketidakberaturan } \\
\text { akibat } \\
\text { pergeseran } \\
\text { tegak lurus } \\
\text { terhadap bidang }\end{array}$ & $x$ & $\begin{array}{l}\text { 4. Ketidakberatu } \\
\text { ran akibat } \\
\text { diskondinuitas } \\
\text { bidang pada } \\
\text { elemen vertikal } \\
\text { pemikul gaya } \\
\text { lateral }\end{array}$ & $x$ \\
\hline $\begin{array}{l}\text { 5. Ketidakberaturan } \\
\text { sistem non } \\
\text { paralel }\end{array}$ & $x$ & $\begin{array}{l}\text { 5.Ketidakberatu } \\
\text { ran tingkat } \\
\text { lunak akibat } \\
\text { diskontinuitas } \\
\text { pada kekuatan } \\
\text { lateral tingkat. }\end{array}$ & $x$ \\
\hline
\end{tabular}

J. Jarak Pemisah Antar Gedung (Dilatasi) Berdasarkan SNI 17262012 pasal 7.12.3 Jarak pemisah antar gedung harus ditentukan paling sedikit sama dengan jumlah simpangan maksimum $\left(\delta_{\mathrm{SM}}\right)$ masing-masing bangunan gedung pada tiap tingkatannya dengan menggunakan persamaan berikut.

$\delta_{\mathrm{SM}}=\left(\mathrm{Cd} \mathrm{x} \delta_{\text {maks }}\right) / \mathrm{I}_{\mathrm{e}}$

Struktur-struktur bangunan yang bersebelahan harus dipisahkan minimal sebesar $\delta_{\mathrm{MT}}$ yang dapat dihitung dengan menggunakan persamaan di bawah ini.

$\delta_{\mathrm{MT}}=\sqrt{ }\left(\delta_{\mathrm{SM} 1}\right)^{2}+\left(\delta_{\mathrm{SM} 2}\right)^{2}$

Tabel 20. Kontrol dilatasi

\begin{tabular}{|c|c|c|c|}
\hline Tinjauan & $\delta_{\mathrm{MT}}$ & $\begin{array}{c}\text { Jarak } \\
\text { dilatasi }\end{array}$ & Cek \\
\hline $\begin{array}{c}\text { Bangunan } \\
\text { A - B } \\
(\text { Arah } x)\end{array}$ & $\begin{array}{c}50,7207 \\
\mathrm{~mm}\end{array}$ & $\begin{array}{l}130 \\
\mathrm{~mm}\end{array}$ & $\begin{array}{c}\delta_{\mathrm{MT}}<\text { jarak } \\
\text { dilatasi } \\
\text { (Aman) }\end{array}$ \\
\hline $\begin{array}{c}\text { Bangunan } \\
\text { B-C } \\
(\text { Arah } x)\end{array}$ & $\begin{array}{c}50,3946 \\
\mathrm{~mm}\end{array}$ & $\begin{array}{l}130 \\
\mathrm{~mm}\end{array}$ & $\begin{array}{c}\delta_{\mathrm{MT}}<\text { jarak } \\
\text { dilatasi } \\
\text { (Aman) }\end{array}$ \\
\hline
\end{tabular}

\section{K. Perhitungan Balok}

Properti material dan penampang

- Lebar balok (b) : $400 \mathrm{~mm}$

- Tinggi balok (h) : $700 \mathrm{~mm}$

- Diameter tulangan pokok : $19 \mathrm{~mm}$

- Diameter tulangan sengkang : $13 \mathrm{~mm}$

- Diameter tulangan torsi : $19 \mathrm{~mm}$

- Selimut bersih (cc) : $40 \mathrm{~mm}$

- Kuat tekan beton (fc') : $25 \mathrm{MPa}$

- Kuat leleh tulangan pokok : $400 \mathrm{MPa}$

- Kuat leleh tulangan sengkang : $240 \mathrm{MPa}$

- $\quad \beta 1$ (SNI 2847:2013 pasal 10.2.7.3) = $\mathrm{f}_{\mathrm{c}}{ }^{\prime} \leq 30$ Mpa maka $\beta 1: 0,85$

- Jumlah tulangan tumpuan atas : 10 buah

- Jumlah tulangan tumpuan bawah : 5 buah

- Jumlah tulangan lapangan atas : 5 buah

- Jumlah tulangan lapangan bawah : 10 buah

- $\lambda$ (Menggunakan beton normal) : 1

Berdasarkan perhitungan yang telah dilakukan, maka akan diperoleh gambar perencaaan sebagai berikut:

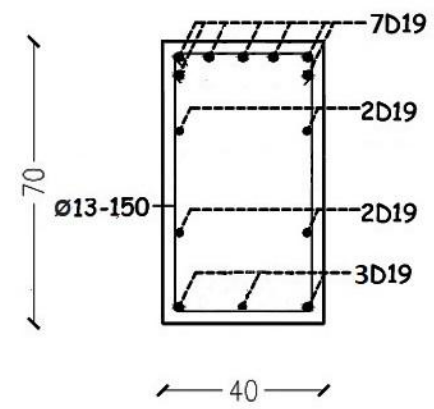

Gambar 7 Penulangan rencana balok B3 tumpuan bangunan A

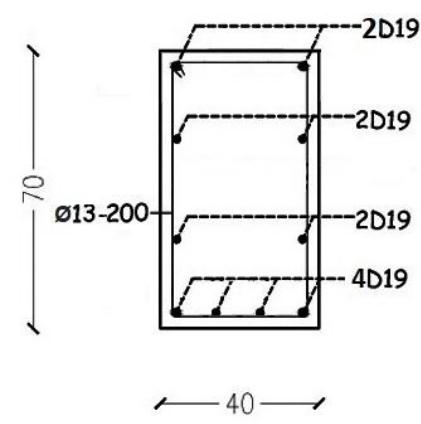

Gambar 8 Penulangan rencana balok B3 lapangan bangunan $\mathrm{A}$ 
Tabel 21. Rekapitulasi penulangan balok

\begin{tabular}{|c|c|c|c|c|c|}
\hline \multirow{2}{*}{$\begin{array}{c}\text { Tipe } \\
\text { balok }\end{array}$} & \multirow[t]{2}{*}{ Lokasi } & \multicolumn{2}{|c|}{ Longitudinal } & \multirow{2}{*}{ Torsi } & \multirow{2}{*}{$\begin{array}{c}\text { Sengk } \\
\text { ang }\end{array}$} \\
\hline & & Atas & Bawah & & \\
\hline $\begin{array}{c}\text { B1 } \\
(20 x 40)\end{array}$ & Tumpuan & 3 D 19 & $2 \mathrm{D} 19$ & - & $\begin{array}{l}\varnothing 13 \\
-150 \\
\end{array}$ \\
\hline $\begin{array}{c}\text { Bangun } \\
\text { an A }\end{array}$ & Lapangan & 2 D 19 & 3 D 19 & - & $\begin{array}{l}\varnothing 13 \\
-200 \\
\end{array}$ \\
\hline $\begin{array}{c}\text { B2 } \\
(30 \times 55)\end{array}$ & Tumpuan & $5 \mathrm{D} 19$ & $2 \mathrm{D} 19$ & $2 \mathrm{D} 19$ & $\begin{array}{l}\varnothing 13 \\
-150 \\
\end{array}$ \\
\hline $\begin{array}{c}\text { Bangun } \\
\text { an A }\end{array}$ & Lapangan & 2 D 19 & $5 \mathrm{D} 19$ & 2 D 19 & $\begin{array}{l}\varnothing 13 \\
-200 \\
\end{array}$ \\
\hline $\begin{array}{c}\text { B3 } \\
(40 \times 70)\end{array}$ & Tumpuan & 7 D 19 & $3 \mathrm{D} 19$ & 4 D 19 & $\begin{array}{l}\varnothing 13 \\
-150 \\
\end{array}$ \\
\hline $\begin{array}{c}\text { Bangun } \\
\text { an A }\end{array}$ & Lapangan & 2 D 19 & 4 D 19 & 4 D 19 & $\begin{array}{l}\varnothing 13 \\
-200 \\
\end{array}$ \\
\hline $\begin{array}{c}\text { B2 } \\
(30 \times 55)\end{array}$ & Tumpuan & 4 D 19 & $2 \mathrm{D} 19$ & $2 \mathrm{D} 19$ & $\begin{array}{l}\varnothing 13 \\
-150 \\
\end{array}$ \\
\hline $\begin{array}{c}\text { Bangun } \\
\text { an B }\end{array}$ & Lapangan & 2 D 19 & 4 D 19 & 2 D 19 & $\begin{array}{r}\varnothing 13 \\
-200 \\
\end{array}$ \\
\hline $\begin{array}{c}\text { B3 } \\
(40 \times 70)\end{array}$ & Tumpuan & 4 D 19 & $2 \mathrm{D} 19$ & 4 D 19 & $\begin{array}{l}\varnothing 13 \\
-150 \\
\end{array}$ \\
\hline $\begin{array}{c}\text { Bangun } \\
\text { an B }\end{array}$ & Lapangan & $2 \mathrm{D} 19$ & 4 D 19 & 4 D 19 & $\begin{array}{l}\varnothing 13 \\
-200 \\
\end{array}$ \\
\hline $\begin{array}{c}\text { B1 } \\
(20 x 40)\end{array}$ & Tumpuan & 3 D 19 & $2 \mathrm{D} 19$ & - & $\begin{array}{l}\varnothing 13 \\
-150 \\
\end{array}$ \\
\hline $\begin{array}{c}\text { Bangun } \\
\text { an } \mathrm{C}\end{array}$ & Lapangan & $2 \mathrm{D} 19$ & $3 \mathrm{D} 19$ & - & $\begin{array}{l}\varnothing 13 \\
-200 \\
\end{array}$ \\
\hline $\begin{array}{c}\mathrm{B} 2 \\
(30 \times 55)\end{array}$ & Tumpuan & $5 \mathrm{D} 19$ & $2 \mathrm{D} 19$ & $2 \mathrm{D} 19$ & $\begin{array}{l}\varnothing 13 \\
-150 \\
\end{array}$ \\
\hline $\begin{array}{c}\text { Bangun } \\
\text { an } \mathrm{C}\end{array}$ & Lapangan & $2 \mathrm{D} 19$ & $5 \mathrm{D} 19$ & $2 \mathrm{D} 19$ & $\begin{array}{l}\varnothing 13 \\
-200 \\
\end{array}$ \\
\hline $\begin{array}{c}\text { B3 } \\
(40 \times 70)\end{array}$ & Tumpuan & 7 D 19 & 3 D 19 & 4 D 19 & $\begin{array}{l}\varnothing 13 \\
-150 \\
\end{array}$ \\
\hline $\begin{array}{c}\text { Bangun } \\
\text { an } \mathrm{C}\end{array}$ & Lapangan & 2 D 19 & 4 D 19 & 4 D 19 & $\begin{array}{l}\varnothing 13 \\
-200 \\
\end{array}$ \\
\hline
\end{tabular}

\section{Perhitungan Kolom}

Properti material dan penampang

- Tinggi kolom (L) : $6500 \mathrm{~mm}$

- Sisi pendek kolom (b): $500 \mathrm{~mm}$

- Sisi panjang kolom (h) : $800 \mathrm{~mm}$

- Diameter tulangan longitudinal : $19 \mathrm{~mm}$

- Diameter tulangan sengkang : $13 \mathrm{~mm}$

- Selimut bersih (cc) : $40 \mathrm{~mm}$

- Kuat tekan beton, (fc') : $25 \mathrm{MPa}$

- Kuat leleh tulangan pokok (fy) : $400 \mathrm{MPa}$

- Kuat leleh tulangan sengkang (fy) : $400 \mathrm{MPa}$

- Tinggi balok (hb) : $700 \mathrm{~mm}$

- Panjang bersih kolom $(\mathrm{Ln})=5800 \mathrm{~mm}$

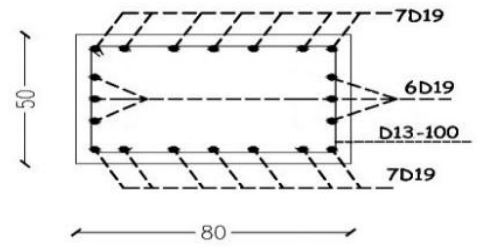

Gambar 9 Penulangan rencana kolom 1 tumpuan

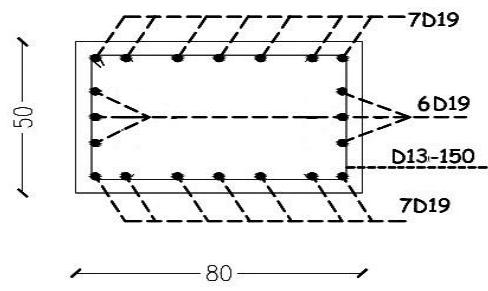

Gambar 10 Penulangan rencana kolom 1 lapangan

Tabel 22. Rekapitulasi penulangan kolom

\begin{tabular}{|c|c|c|c|}
\hline Tipe kolom & Lokasi & Longitudinal & Sengkang \\
\hline \multirow{2}{*}{$\begin{array}{c}\text { K1 (80x50) } \\
\text { Bangunan } \\
\text { A }\end{array}$} & Tumpuan & 20 D 19 & D $13-100$ \\
\hline & ( & $20 \mathrm{D} 19$ & D $13-150$ \\
\hline \multirow{2}{*}{$\begin{array}{c}\text { K2 (50x50) } \\
\text { Bangunan } \\
\text { A }\end{array}$} & Tum & $16 \mathrm{D} 19$ & D $10-100$ \\
\hline & Lapangan & $16 \mathrm{D} 19$ & D $10-150$ \\
\hline \multirow{2}{*}{$\begin{array}{c}\text { K1 (80x50) } \\
\text { Bangunan } \\
\text { A }\end{array}$} & Tumpuan & $20 \mathrm{D} 19$ & D $13-100$ \\
\hline & Lapa & & D $13-150$ \\
\hline \multirow{2}{*}{$\begin{array}{c}\text { K2 (50x50) } \\
\text { Bangunan } \\
\text { A }\end{array}$} & 1 & $16 D 10$ & D $10-100$ \\
\hline & I & $16 \mathrm{I}$ & D $10-150$ \\
\hline \multirow{2}{*}{$\begin{array}{c}\text { K1 (80x50) } \\
\text { Bangunan } \\
\text { A } \\
\end{array}$} & Tumpuan & $20 \mathrm{D} 19$ & D $13-100$ \\
\hline & Lapangan & $20 \mathrm{D} 19$ & D $13-150$ \\
\hline \multirow{2}{*}{$\begin{array}{c}\text { K2 (50x50) } \\
\text { Bangunan } \\
\text { A } \\
\end{array}$} & 1 & 9 & D 10 \\
\hline & Lapangan & $16 \mathrm{D} 19$ & D $10-150$ \\
\hline
\end{tabular}

\section{Perhitungan Plat}

Data plat lantai adalah sebagai berikut.

- Kuat tekan beton : $25 \mathrm{Mpa}$

- Tegangan leleh tulangan lentur : $240 \mathrm{MPa}$

- Panjang bentang plat arah x (Lx): $3800 \mathrm{~mm}$

- Panjang bentang plat arah y (Ly) : $4000 \mathrm{~mm}$

- Tebal pelat lantai (h) : $120 \mathrm{~mm}$

- Diameter tulangan : $\varnothing 10 \mathrm{~mm}$

- Tebal bersih selimut beton : $20 \mathrm{~mm}$ 


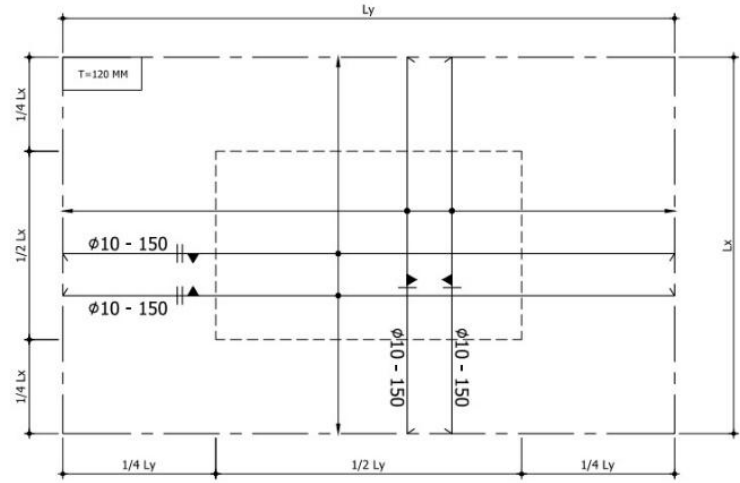

Gambar 11 Tampak atas penulangan rencana plat

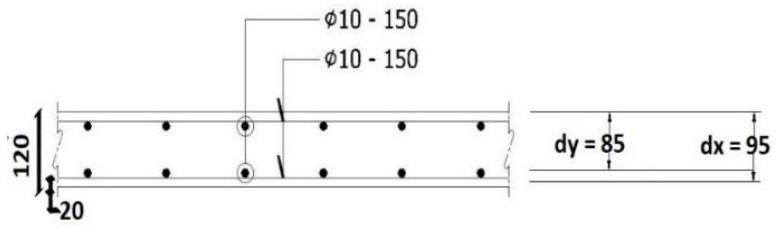

Gambar 12 Detail penulangan rencana plat

Berdasarkan perhitungan yang telah dilakukan, digunakan diameter dan jarak yang sama untuk plat lantai dan plat atap pada bangunan A, B, dan C, yaitu:

- Tulangan tumpuan arah $\mathrm{x}: \varnothing-150$

- Tulangan lapangan arah $\mathrm{x}: \varnothing-150$

- Tulangan tumpuan arah y : Ø-150

- Tulangan lapangan arah y : Ø-150

\section{KESIMPULAN DAN SARAN}

\section{A. Kesimpulan}

Dari hasil analisis penulisan ini dapat diambil kesimpulan seperti berikut ini:

1. Dari hasil pemodelan struktur 3D yang dilakukan oleh program Etabs v.16, struktur gedung yang dianalisis masuk dalam kategori aman.

2. Bangunan $\mathrm{A}, \mathrm{B}$, dan $\mathrm{C}$ tidak mengalami ketidak beraturan struktur vertikal dan horizontal.

3. Dilatasi antara bangunan sudah aman dan memenuhi persyaratan SNI 1726:2012 dan SNI 03 1726:2002.

4. Terdapat perbedaan dimensi komponen struktur pada hasil analisis dengan keadaan eksisting dikarenakan pada analisis ini tidak memperhitungan tangga.

\section{B. Saran}

Berdasarkan hasil penelitian pada tugas akhir ini, beberapa saran yang dapat diberikan mengenai tinjauan struktur bangunan gedung rumah sakit ini antara lain sebagai berikut:

1. Dibutuhkan literatur dan sumber referensi yang mendukung dalam penulisan tugas akhir ini supaya mempermudah dalam proses analisis yang dilakukan.

2. Dalam menganalisis suatu bangunan harus diketahui fungsi/kegunaan bangunan tersebut, supaya dalam tahap perhitungan mampu memperoleh hasil yang efektit dan meminimalisasi terjadinya kegagalan struktur.

3. Dalam melakukan analisis menggunakan program, harus selalu dipastikan bahwa data material dan beban-beban yang diinput ke dalam program harus sesuai dengan peraturan yang berlaku di Indonesia.

4. Perlu menguasai aplikasi atau program perhitungan agar mempermudah proses pengerjaan.

\section{DAFTAR PUSTAKA}

Amdhani, P., 2012. Perencanaan Struktur Gedung Beton Bertulang Sistem Rangka Pemikul Momen Menengah, Universitas Negeri Yogyakarta, Yogyakarta.

Insinyursipil, 2015. Perhitungan Lendutan Plat Lantai. http://www. http://insinyursipil.blogspot.com/2015/01/ perhitungan-lendutan-pelat-lantai.html, [diakses bulan November 2020].

Medianeliti, 2017. Jenis-jenis Balok. https://media.neliti.com/media/publication s/140486-ID-evaluasi-balok-dan-kolomsede.pdf, [diakses bulan November 2020].

PMK, 2019. Klasifikasi dan Perizinan Rumah Sakit, Menteri Kesehatan Republik Indonesia, Jakarta.

Puskim, 2011. Desain Spektra Indonesia http://puskim.pu.go.id/Aplikasi/desain_spe ktra_indonesia_2011/, [diakses bulan Juli 2020].

Slidshare, 2014. Klasifikasi Plat Lantai pada Bangunan.

https://www.slideshare.net/AbrahamLcn/p elat-lantai, [diakses bulan September 2020].

Spesialiskonstruksi, 2018. Konstruksi

Komposit.

https://www.spesialiskonstruksi.com/2018 /12/konstruksi-komposit.html, [diakses bulan Maretr 2020].

Syukri, N., 2016. Tinjauan Kekuatan Struktur Kolom, Blok, dan Pelat pada Proyek Pembangunan Klenteng Ho Tek Chieng Sin, Politeknik Negeri Manado, Manado.

Wardhani, Anedya. 2015. Dilatasi materi kuliah Teknologi Bangunan 3. Fakultas Teknik Arsitektur Universitas Pancasila : Jakarta. 